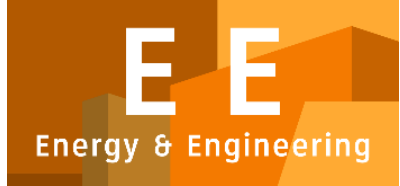

PAPER - OPEN ACCESS

\title{
Perancangan Jadwal Perawatan Mesin Menggunakan Pendekatan Reliability Centered Maintenance (RCM) pada PT. XYZ
}

$\begin{array}{ll}\text { Author } & : \text { Nurhayati Sembiring } \\ \text { DOI } & : 10.32734 / \text { ee } . v 1 i 2.245 \\ \text { Electronic ISSN } & : 2654-7031 \\ \text { Print ISSN } & : 2654-704 X\end{array}$

Volume 1 Issue 1 - 2018 TALENTA Conference Series: Energy and Engineering

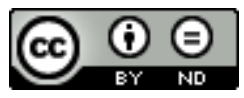

This work is licensed under a Creative Commons Attribution-NoDerivatives 4.0 International License.

Published under licence by TALENTA Publisher, Universitas Sumatera Utara
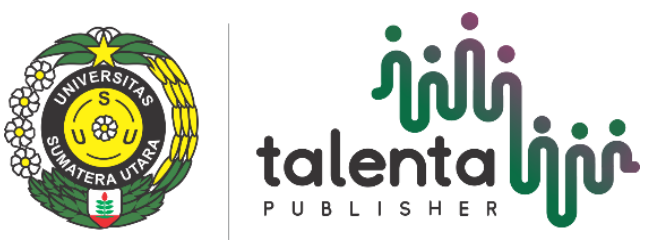


\title{
Perancangan Jadwal Perawatan Mesin Menggunakan Pendekatan Reliability Centered Maintenance (RCM) pada PT. XYZ
}

\author{
Nurhayati Sembiring ${ }^{\mathrm{a}}$, Gita Ade Elvira ${ }^{\mathrm{b}}$ \\ ${ }^{a, b}$ Departemen Teknik Industri, Fakultas Teknik, Medan, 20155, Universitas Sumatera Utara \\ nurhayatipandia68@yahoo.com, elvira.gita08@gmail.com
}

\begin{abstract}
Abstrak
PT. XYZ adalah suatu perusahaan yang bergerak dalam bidang usaha perkebunan dan pengolahan hasil perkebunan.Produk utamanya adalah Minyak Sawit (CPO) dan Inti Sawit (Kernel). Apabila terjadi kerusakan mesin pada saat jam kerja mesin, maka proses produksi tidak berjalan. Untuk itu diperlukan sistem perawatan yang terjadwal. Tujuan dari penelitian ini adalah mengidentifikasi sumber utama kerusakan mesin, menganalisis kerusakan komponen kritis mesin dengan metode Reliability Centered Maintenance dan membuat jadwal perawatan mesin yang terencana. Komponen kritis pada mesin Screw Press yang dianalisaadalah Gearbox, Hydraulic Double Cone dan Van Belt. Hasil penelitian menunjukan selang waktu penggantian komponen Gearbox adalah 94 hari, komponen Hydraulic Double Cone adalah 105 hari dan komponen Van Belt adalah 116 hari.
\end{abstract}

Keywords: Preventive Maintenance; Reliability Centered Maintenance (RCM); Screw Press

\section{Pendahuluan}

Salah satu faktor penunjang keberhasilan suatu industri manufaktur ditentukan oleh kelancaran proses produksi. Sehingga bila proses produksi lancar, penggunaan mesin dan peralatan produksi yang efektif akan menghasilkan produk berkualitas, waktu penyelesaian pembuatan yang tepat dan ongkos produksi yang murah. Proses tersebut tergantung dari kondisi sumber daya yang dimiliki seperti manusia, mesin ataupun sarana penunjang lainnya, dimana kondisi yang dimaksud adalah kondisi siap pakai untuk menjalankan operasi produksinya, baik ketelitian, kemampuan ataupun kapasitasnya. Berdasarkan penelitian yang telah dilakukan oleh Al-Ghamdi, dkk yang berpendapat bahwa metode Reliability Centered Maintenance ( $R C M)$ adalah pendekatan yang efektif untuk pengembangan program-program $P M$ dalam meminimalkan kegagalan peralatandan menyediakan plant di industridengan alat-alat yang efektif dan kapasitasoptimal untuk memenuhi permintaanpelanggan dan unggul dalam persaingan. Dengan penerapan sistem kebijaksanaan perawatan yang tepat dan sistematis, metode $R C M$ dapat digunakan untuk meningkatkan efisiensi dengan mereduksi biaya perawatan namun tetap mempertahankan nilai dan keandalan dari asset yang dimiliki oleh suatu perusahaan sebagai strategi dalam menghadapi lingkungan yang kompetitif.Selain itu, metode $R C M$ mempunyai keunggulandalam menentukan program pemeliharaanyang berfokus pada komponen atau mesin-mesinyang kritis (critical item list) danmenghilangkan kegiatan perawatan yangtidak diperlukan dengan menentukaninterval pemeliharaan yang optimal [1].

Muhammad Tahrir Aziz dalam penelitiannya menyebutkan bahwa Penerapan metode RCM akan memberikan keuntungan yaitu : keselamatan dan integritas lingkungan menjadi lebih lebih diutamakan, prestasi operasional yang 
meningkat, efektifitas biaya operasi dan perawatan yang lebih rendah, meningkatkan ketersediaan dan reliabilitas peralatan, umur komponen yang lebih lama, basis data yang lebih komprehensif, motivasi individu yang lebih besar, dan kerja sama yang baik diantara bagian-bagian dalam suatu instalasi [2]. Menurut Assauri perawatan diartikan sebagai suatu kegiatan pemeliharaan fasilitas pabrik serta mengadakan perbaikan, penyesuaian atau penggantian yang diperlukan agar suatu keadaan operasi produksi sesuai dengan yang direncanakan. Hal ini dapat dicapai dengan cara mengurangi kemacetan atau kendala sekecil mungkin, sehingga sistem dapat bekerja secara efisien. Namun seringkali yang terjadi adalah kelalaian dan perawatan baru diingat apabila kerusakan telah terjadi dalam sistem produksi yang menyebabkan penambahan biaya perawatan. Namun apabila perawatan dilakukan dengan menyeluruh dan teratur maka akan berguna untuk menjamin kontinuitas proses produksi dan umur dari fasilitas produksi tersebut [3].

Berdasarkan hasil dari penelitian yang dilakukan oleh Hendro Asisco, dkk menyarankan agar Reliability Centered Maintenance (RCM) ini dapat diterapkan sebagai pendekatan yang digunakan dalam sistem perawatan di PT. Perkebunan Nusantara VII (Persero) UU Sungai Niru.Perusahaan tersebut menerapkan sistem corrective maintenance sehingga sering mengalami permasalahan breakdown yang sangat tinggi.Hal tersebut menghambat jalannya produksi sehingga berdampak pada penurunan kapasitas produksi [4].Penerapan RCM telah dilakukan oleh Evi Febianti pada penelitiannya di PT. XYZ yang bergerak dibidang manufaktur dengan hasil produksi baja profil dan baja tulangan. Saat ini proses produksi perusahaan berlangsung secara terus-menerus. Salah satu mesin yang digunakan adalah mesin roughing stand dengan mesin yang memiliki waktu downtime terbesar [5].Pendapat lain menyatakan RCM adalah metode yang menawarkan strategi terbaik bagi perawatan pencegahan. Cara-cara RCM yang mendasar diuraikan dalam preserve function (pemeliharaan fungsi), identifity failure modes that can defeat the function,priotize function need, select only applicable andeffective preventive maintenance (PM) tasks [6].Ben-Daya dalam Asisco, H menyatakan bahwa RCM merupakan landasan dasar untuk perawatan fisik dan suatu teknik yang dipakai untuk mengembangkan perawatan pencegahan (preventive maintenance) yang terjadwal. Metode RCM diharapkan dapat menetapkan schedule maintenance dan dapat mengetahui secara pasti tindakan kegiatan perawatan (maintenance task) yang tepat yang harus dilakukan pada setiap komponen mesin [7].

Untuk mengatasi masalah yang terdapat pada PT. XYZ maka penelitian ini mencoba untuk mengusulkan sistem perawatan mesin dengan menggunakan metode Reliability Centered Maintenance (RCM).Metode RCM diharapkan dapat menetapkan schedulemaintenance dan dapat mengetahui secara pasti tindakan kegiatan perawatan (maintenance task) yang tepat yang harus dilakukan pada setiap komponen mesin yang mengalami kerusakan.Perusahaan menggunakan mesin-mesin yang beroperasi selama 2 shift kerja. Apabila terjadi kerusakan mesin pada saat jam kerja mesin, maka proses produksi tidak berjalan. Untuk itu diperlukan sistem perawatan yang sudah terjadwal pada mesin-mesin/ peralatan produksi di perusahaan untuk meminimisasi terhambatnya proses produksi jika terjadi kerusakan. Saat ini, yang menjadi jenis kendala dalam produksi yang terjadi di PTPN III Sei Mangkei adalah tidak berjalan lancarnya kegiatan produksi di lantai produksi akibat terjadinya kerusakan mesin produksi sehingga menghambat ataupun menghentikan proses produksi.

\section{Metodologi Penelitian}

Penelitian dilaksanakan di PT. XYZ yang memproduksi Crude Palm Oil (CPO) dan Palm Kernel Oil (PKO). Jenis penelitian yang digunakan adalah penelitian deskriptif (Descriptive Research), yaitu penelitian yang bertujuan untuk mendeskripsikan secara sistematis faktual dan akurat berdasarkan data-data. Jadi penelitian ini meliputi proses pengumpulan data, pengolahan data, serta analisis pemecahan masalah.Hasil penelitian bertujuan untuk memberikan usulan jadwal penggantian komponen mesin.Objek penelitian yang diamati adalah mesin yang memiliki tingkat kerusakan tinggi ditinjau dari nilai downtime tertinggi pada PT. XYZ. Langkah-langkah proses penelitian dapat dilihat pada Gambar 1. 


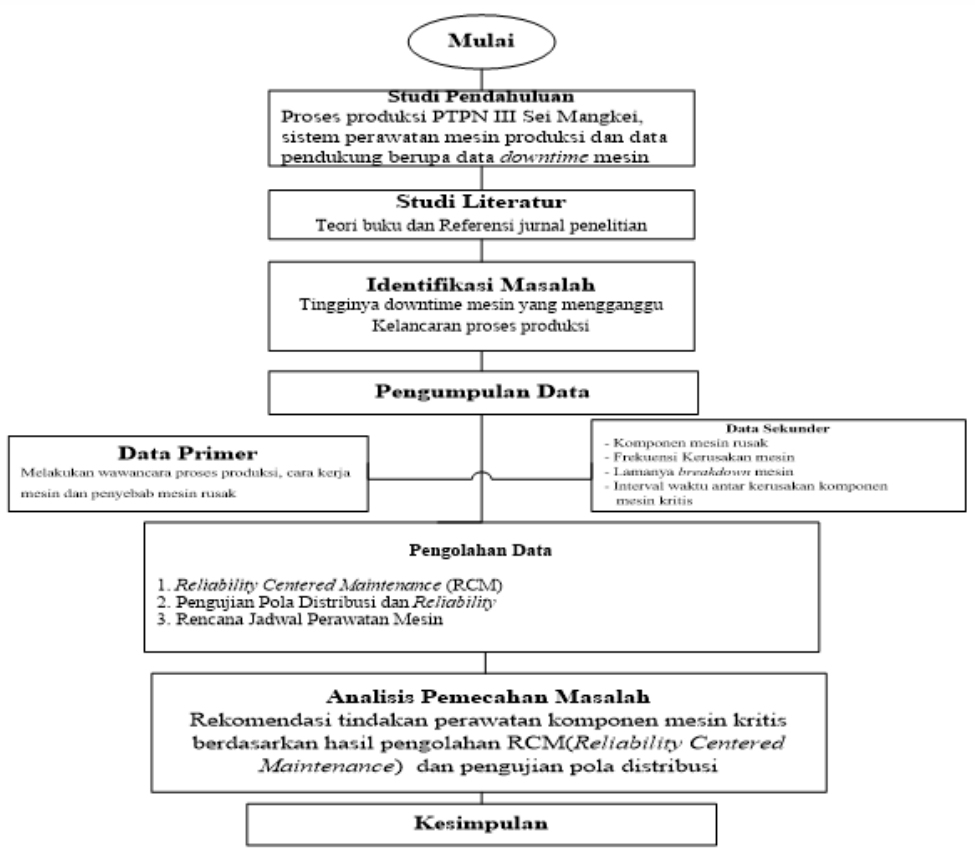

Gambar. 1. Langkah-langkah Proses Penelitian

\section{Hasil dan Pembahasan}

\subsection{Penentuan Komponen Kritis}

Data frekuensi kerusakan komponen mesin kritis Screw press dikumpulkan berdasarkan dokumen atau data historis bagian teknik di PT. XYZ. Interval waktu antar kerusakan komponen adalah selang waktu antara kerusakan yang terjadi saat ini dengan kerusakaan yang terjadi setelahnya. Komponen kritis penyebab mesin screw press mengalami kerusakan adalah Gearbox, Hydraulic double cone dan Van Belt.

\subsection{Failure Mode and Effect Analysis (FMEA)}

RCM mendefinisikan kegagalan (failure) sebagai kondisi yang tidak memuaskan (unsatisfactory) atau tidak memenuhi harapan, sebagai ukurannya adalah berjalannya fungsi sesuai performance standard yang ditetapkan. FMEA berguna untuk memprediksi komponen mana yang kritis, yang sering rusak dan jika terjadi kerusakan pada komponen tersebut maka sejauh mana pengaruhnya terhadap fungsi sistem secara keseluruhan pada produksi pengolahan kelapa sawit. Penentuan RPN komponen mesin kritis PT. XYZ dapat dilihat pada Tabel 1. 
Tabel. 1. Penentuan RPN komponen mesin kritis.

\begin{tabular}{|c|c|c|c|c|c|c|c|c|}
\hline No & Parts & Failure Mode & Failure Causes & $\begin{array}{l}\text { Failure } \\
\text { Effect }\end{array}$ & Severity & Occurance & Detection & RPN \\
\hline 1 & Gearbox & Gearbox rusak & $\begin{array}{l}\text { - Kurang } \\
\text { pelumas } \\
\text { - Patahnya } \\
\text { bearing as } \\
\text { akibat } \\
\text { tekanan yang } \\
\text { berlebihan }\end{array}$ & $\begin{array}{l}\text { Tidak } \\
\text { dapat } \\
\text { mengatur } \\
\text { kecepatan } \\
\text { gerak }\end{array}$ & 6 & 3 & 5 & 90 \\
\hline 2 & $\begin{array}{l}\text { Hydraulic } \\
\text { Double } \\
\text { Cone }\end{array}$ & $\begin{array}{l}\text { Hydraulic } \\
\text { Double Cone } \\
\text { rusak }\end{array}$ & $\begin{array}{l}\text { - Tekanan } \\
\text { yang tidak } \\
\text { sesuai } \\
\text { - Electromotor } \\
\text { terbakar }\end{array}$ & $\begin{array}{l}\text { Umur } \\
\text { pakai } \\
\text { berkurang }\end{array}$ & 10 & 6 & 4 & 240 \\
\hline 3 & Van Belt & $\begin{array}{l}\text { Van } \\
\text { Beltpecah/retak }\end{array}$ & $\begin{array}{l}\text { - Posisi } \\
\text { pemasangan } \\
\text { tidak tepat } \\
\text { - Mengalami } \\
\text { aus }\end{array}$ & $\begin{array}{l}\text { Umur } \\
\text { pakai } \\
\text { berkurang }\end{array}$ & 9 & 5 & 3 & 135 \\
\hline
\end{tabular}

Pengujian ini menghasilkan RPN tertinggi sebesar 240 pada komponen Hydraulic Double Cone dengan bentuk kegagalan berupa electromotor terbakar karena tekanan yang tidak sesuai. Pada hasil FMEA peralatan yang memiliki RPN tertinggi akan diprioritaskan dalam kegiatan perawatan. Urutan komponen yang memiliki RPN tertinggi sampai yang terendah adalah Hydraulic Double Cone, Van Belt dan Gear Box.

\subsection{Logic Tree Analysis (LTA)}

Logic Tree Analysis (LTA) mengandung informasi nomor, nama kegagalan fungsi, komponen yang mengalami kegagalan, fungsi komponen dan mode kerusakan komponen, analisis kekritisan. Adapun rekapitulasi LTA (Logic Tree Analysis) untuk komponen yang menyebabkan kegagalan fungsi sistem produksi pengolahan kelapa sawit dapat dilihat pada Tabel 2.

Tabel. 2. Rekapan Identifikasi Hasil LTA pada PT. XYZ

\begin{tabular}{lllllll}
\hline No & Parts & Failure Mode & Evident & Safety & Outage & Category \\
\hline 1 & Gearbox & Gearbox rusak & Y & T & Y & B \\
2 & $\begin{array}{l}\text { Hydraulic } \\
\text { Double } \\
\text { Cone }\end{array}$ & $\begin{array}{l}\text { Hydraulic } \\
\text { Double Cone } \\
\text { rusak }\end{array}$ & Y & T & Y & B \\
3 & Van Belt & $\begin{array}{l}\text { Van } \\
\text { Beltpecah/retak }\end{array}$ & Y & T & Y & B \\
\hline
\end{tabular}

\subsection{Pemilihan Tindakan}

Pemilihan tindakan pada RCM harus memberikan hasil-hasil yang nyata / jelas. Berikut ini adalah rekapan rekapan tindakan perawatan berdasarkan Road Map dapat dilihat pada Tabel 3.

Tabel. 3. Pemilihan Tindakan Perawatan Mesin Screw Press pada PT. XYZ

\begin{tabular}{|c|c|c|c|c|c|c|c|c|c|c|}
\hline \multirow{2}{*}{ No } & \multirow{2}{*}{ Parts } & \multirow{2}{*}{ Failure Mode } & \multicolumn{7}{|c|}{ Selection Guide } & \multirow{2}{*}{$\begin{array}{l}\text { Selection } \\
\text { Task }\end{array}$} \\
\hline & & & 1 & 2 & 3 & 4 & 5 & 6 & 7 & \\
\hline 1 & Gearbox & Gearbox rusak & $\mathrm{Y}$ & $\mathrm{Y}$ & $\mathrm{T}$ & $\mathrm{T}$ & - & $\mathrm{Y}$ & - & T.D \\
\hline 2 & $\begin{array}{l}\text { Hydraulic } \\
\text { Double } \\
\text { Cone }\end{array}$ & $\begin{array}{l}\text { Hydraulic } \\
\text { Double Cone } \\
\text { rusak }\end{array}$ & $\mathrm{Y}$ & $\mathrm{Y}$ & $\mathrm{T}$ & $\mathrm{T}$ & - & $\mathrm{Y}$ & - & T.D \\
\hline 3 & Van Belt & $\begin{array}{l}\text { Van } \\
\text { Beltpecah/retak }\end{array}$ & $\mathrm{Y}$ & $\mathrm{Y}$ & $\mathrm{T}$ & $\mathrm{T}$ & - & $\mathrm{Y}$ & - & T.D \\
\hline
\end{tabular}


Pemilihan tindakan pencegahan berdasarkan hasil analisis terhadap FMEA dan LTA adalah sebagai berikut:

- Time Directed (T.D) yaitu tindakan yang diambil yang lebih berfokus pada aktivitas pergantian yang dilakukan secara berkala. Komponen yang termasuk dalam pemilihan tindakan ini adalah:

- Gearbox

- Van Belt

- Hydraulic Double Cone

\subsection{Pengujian Distribusi}

Pengujian distribusi dilakukan pada masing - masing komponen mesin kritis.Hasil pengujian pola distribusi yang terpilih untuk masing-masing komponen mesin dapat dilihat pada Tabel 4.Pola distribusi yang terpilih adalah distribusi yang mendapatkan nilai Index of Fit (Correlation Coefficient) terbesar.

Tabel. 4. Rekapitulasi Pola Distribusi Kerusakan Komponen Kritis Mesin Screw Press

\begin{tabular}{lll}
\hline No & Nama Komponen & Distribusi \\
\hline 1 & Gearbox & Weibull \\
2 & Hydrolic Double & Normal \\
& Cone & \\
3 & Van Belt & Weibull \\
\hline
\end{tabular}

\subsection{Perhitungan Parameter dan MTTF Komponen Mesin}

Perhitungan MTTF (Mean Time To Failure) dipergunakan sebagai parameter penentuan penggantian komponen mesin. Hasil rekapitulasi perhitungan MTTF, maka didapat interval pergantian masing-masing komponen dapat dilihat pada Tabel 5.

Tabel. 5. Rekapitulasi Nilai MTTF

\begin{tabular}{lll}
\hline No & Komponen & MTTF (hari) \\
\hline 1 & Gearbox & 94 \\
2 & Hydraulic Double & 105 \\
& Cone & \\
3 & Van Belt & 116 \\
\hline
\end{tabular}

Berdasarkan tabel diatas dapat dilihat bahwa komponen Gearbox dengan nilai MTTF 94 hari, maka pada saat mesin dioperasikan selama 94 hari, komponen gearbox sudah harus diganti dan kebutuhan akan komponen pasti tersedia di gudang karena telah direncanakan sebelumnya. Begitu juga dengan komponen hydraulic double cone dengan nilai MTTF 105 hari, maka pada saat mesin dioperasikan selama 105 hari, komponen Hydraulic double cone sudah harus diganti dan kebutuhan akan komponen pasti tersedia di gudang karena telah direncanakan sebelumnya. Kemudian komponen van belt dengan nilai MTTF 116 hari, maka pada saat mesin dioperasikan selama 116 hari, komponen van belt sudah harus diganti dan kebutuhan akan komponen pasti tersedia di gudang karena telah direncanakan sebelumnya.

\section{Diskusi}

\subsection{Analisis Jenis dan Komponen Mesin Kritis}

Mesin Screw Press merupakan alat yang digunakan dalam proses pemisahan minyak. Mesin ini sering mengalami kerusakan disebabkan oleh beberapa hal diantaranya adalah:

- Patahnya bearing as akibat tekanan yang berlebihan.

- Tekanan yang tidak sesuai pada Hydraulic double cone yang dapat menyebabkan electromotor terbakar

- Posisi pemasangan komponen yang tidak tepat sehingga van belt pecah/retak

- Kurangnya pelumas yang menyebabkan aus 


\subsection{Analisis Pola Distribusi}

Pengujian pola distribusi dilakukan terhadap komponen kritis mesin screw press antara lain gearbox berdistribusi weibull, hydraulic double cone berdistribusi normal, danvan belt berdistribusi weibull. Pola distribusi kerusakan komponen kritis mesin diuji dengan menghitung index of fit. Nilai index of fit terbesar merupakan distribusi terpilih pada setiap komponen mesin screw press. Pengujian pola distribusi ini dilakukan dengan menggunakan data interval waktu kerusakan tiap komponen.

\subsection{Analisis Jadwal Perawatan Komponen}

Perawatan mesin usulan adalah dengan menyusun jadwal perawatan komponen mesin yang jadwalnya didapatkan dengan melakukan pengujian pola distribusi terhadap setiap komponen kritis lalu menghitung nilai MTTF (Mean Time To Failure) yang menjadi jadwal perawatan komponen. Berdasarkanestimasi parameter yang diperoleh dari setiap pola distribusi terpilih maka didapat nilai MTTF untuk setiap komponen kritis adalah untuk komponen gearbox adalah 94 hari, komponen hydraulic double cone adalah 105 hari dan komponen van belt adalah 116 hari. Artinya ialah bahwa komponen mesin sudah harus mendapatkan perawatan seperti perbaikan ataupun pergantian komponen yang rusak pada saat beroperasi selama 94 hari untuk komponen gearbox, dan selanjutnya untuk setiap komponen kritis.

\section{Kesimpulan}

Dari hasil penelitian yang telah dilakukan maka dapat diambil kesimpulan bahwa mesin kritis yang menjadi prioritas pembahasan penelitian adalah mesin Screw press yaitu mesin dengan frekuensi kerusakan terbesar selamaperiode 2015-2016. Jenis kerusakan dari komponen kritis mesin screw press yaitu patahnya bearing as akibat tekanan yang berlebihan, tekanan yang tidak sesuai pada Hydraulic double cone yang dapat menyebabkan electromotor terbakar, posisi pemasangan komponen yang tidak tepat sehingga van belt pecah/retak dan kurangnya pelumas yang menyebabkan aus. Komponen mesin screw press yang perlu dilakukan pergantian komponen dalam periode waktu tertentu yaitu gearbox, hydraulic double cone dan van belt. Pola distribusi dari komponen kritis mesin screw press antara lain: komponen gearbox berdistribusi weibull, komponen hydraulic double cone berdistribusi normal dan komponen van belt berdistribusi weibull. Jadwal perawatan komponen kritis untuk komponen gearbox adalah 94 hari, komponen hydraulic double cone adalah 105 hari dan komponen van belt adalah 116 hari.

\section{Daftar Pustaka}

[1] Blanchard, Benjamin. (1994). "Maintainability a Key to Effective Serviceability and maintenance Managesment”. New York: A WileyInterscience Publication

[2] Charless, Ebelling. (1997). “Reliability and Maintainability Engineering”. New York : Unoversity of Dayton.

[3] Corder, Antony. (1997). “Teknik Manajemen Pemeliharaan”. Jakarta: Erlangga.

[4] Corder, Antony. (1992). "Teknik Manajemen Pemeliharaan”. Jakarta: Erlangga

[5] Ebeling, Charles E. (1997). "Reliability and Maintainability Engineering”. Singapore: McGraw Hill

[6] Jardine, A.K.S. (2006). Maintenance, Replacement, and Reliability. Taylor and Francis Group. New York: LLC

[7] IAEA. (2008). "Application of Reliability Centered Maintenance to Optimize Operation and Maintenance in Nuclear Power Plants".

[8] Rohman, Muhammad. (2014). "Analisa Perbandingan Model Replacement di PT. Papertech Indonesia Magelang”.

[9] Smith, Anthony. (2003). "RCM Gateway to World Class Maintenance”. USA: Elsevier.

[10]Tahril, Aziz. “Penerapan Metode RCM Berbasis WEB pada Sistem Pendingin di Reaktor Serba Guna Ga. Siwabess”y. Yogyakarta: UGM. 